\title{
PRODUKSI BIODIESEL DARI DEDAK PADI SECARA IN SITU DENGAN TEKNOLOGI MICROWAVE
}

\author{
Yulia Tri Rahkadima*1, Qurrota A’yuni ${ }^{1,2}$ \\ ${ }^{1}$ Program Studi Teknik Kimia, Fakultas Teknik, Universitas Nahdlatul Ulama Sidoarjo \\ ${ }^{2}$ Departemen Kimia, Fakultas Sains dan Teknologi, Universitas Airlangga \\ *email: yuliarahkadima@gmail.com
}

Received 07 November 2019

Accepted 31 Desember 2019

\begin{abstract}
Abstrak
Proses produksi biodiesel dari dedak padi dengan memanfaatkan microwave secara in situ telah berhasil dilakukan. Pengaruh jumlah metanol dan waktu reaksi terhadap kandungan FAMEs dalam produk dipelajari dalam penelitian ini. Dedak padi, metanol dan katalis basa berupa $\mathrm{NaOH} 0.6 \mathrm{w} \%$ dimasukkan ke dalam labu alas datar dilengkapi dengan kondensor dan dimasukkan ke dalam reaktor microwave yang telah dimodifikasi. Produk reaksi yang berupa campuran FAMEs, gliserol, reaktan yang tidak bereaksi dan komponen lainnya kemudian dicuci menggunakan $n$ - heksana dan dilanjut dilakukan proses distilasi. Hasil penelitian menunjukan bahwa dengan menggunakan reaktor microwave, kandungan FAMEs lebih tinggi diperoleh dengan waktu reaksi yang lebih singkat. Gelombang mikro berhasil mempercepat terjadinya reaksi transesterifikasi. Kandungan FAMEs tertinggi yaitu $6.2036 \%$ diperoleh pada waktu reaksi 10 menit, metanol $60 \mathrm{ml}$ dan suhu reaksi $60^{\circ} \mathrm{C}$.
\end{abstract}

Kata kunci : Biodiesel, In situ, Microwave, Dedak padi

\begin{abstract}
The process of biodiesel production from rice bran using in situ microwaves has been successfully carried out. The effect of the amount of methanol and reaction time on the FAMEs content in the product was studied in this study. Rice bran, methanol and alkaline catalyst in the form of $0.6 \mathrm{w} \% \mathrm{NaOH}$ are put into a flat bottom flask equipped with a condenser and put into a modified microwave reactor. The reaction product in the form of a mixture of FAMEs, glycerol, unreacted reactants and other components is then washed using n-hexane and contuining with the distillation process. The results showed that by using a microwave reactor, a higher FAMEs content was obtained with a shorter reaction time. Microwaves successfully accelerate the transesterification reaction. The highest FAMEs content of $6.2036 \%$ was obtained at a reaction time of 10 minutes, methanol 60 $\mathrm{ml}$ and reaction temperature $60^{\circ} \mathrm{C}$.
\end{abstract}

Keywords: Biodiesel, In situ, Microwave, Rice bran

\section{Pendahuluan}

Energi terbarukan merupakan subjek penting penelitian dalam beberapa dekade terakhir. Hal ini disebabkan oleh berkurangnya cadangan minyak bumi sebagai sumber utama energi dunia. Berbagai energi alternatif terbarukan dikembangkan untuk memenuhi kebutuhan energi di massa depan, diantaranya panel surya, hidrogen, biodiesel dan bioetanol (Rahkadima dan A'yuni, 2017). Biodiesel merupakan energi alternatif yang menjanjikan untuk dikembangkan karena energi ini memiliki keunggulan dibandingkan energi alternatif 
lain. Berbahan baku biomasssa yang tersedia melimpah di alam menjadikan biodiesel murah untuk dikembangkan. Kandungan oksigen dalam biodiesel lebih tinggi dibandingkan bahan bakar fosil sehingga dapat mengurangi emisi karbon, monoksida, poliaromatik, sulfur, hidrokarbon dan lain lain (Lin, et al., 2009). Selain itu, tidak dibutuhkan modifikasi mesin untuk menggunakan biodiesel adalah salah satu keunggulan lain.

Biodiesel dibuat dengan mereaksikan trigliserida (TG) sebagai komposisi utama minyak dengan alkohol untuk menghasilkan fatty acid metil ester (FAME) dan produk samping berupa gliserol (Lin et al., 2009). Berbagai bahan baku dan metode telah dikembangkan untuk mendapatkan skema terbaik untuk produksi biodiesel. Dedak padi merupakan salah satu limbah dari proses penggilingan padi yang memiliki jumlah besar di Indonesia. Pada periode JanuariSeptember tahun 2018, data Badan pusat statistik menyebutkan bahwa produksi padi nasional sebesar 49,65 juta ton dan potensi jumlah dedak padi adalah sebesar 4,965 juta ton, sepuluh persen dari total produksi padi (Astawan dan Febrinda, 2010). Melimpahnya ketersediaan dedak padi menjadikan dedak padi menjadi bahan baku pembuatan biodiesel yang menjanjikan untuk dikembangkan di Indonesia.

Teknologi microwave telah menjadi alternatif metode yang menjanjikan dalam produksi biodiesel. Hal ini disebabkan teknologi ini dapat menkonversi dengan cepat TG menjadi FAME dengan kondisi operasi moderate. Microwave memberikan pemanasan yang merata pada molekul yang bereaksi sehingga dapat mempercepat laju reaksi (Gude et al., 2013). Efektifitas gelombang mikro dalam proses ekstraksi dipengaruhi oleh beberapa faktor yaitu pemilihan pelarut, selektifitas pelarut dan sifat dielektrik pelarut (Gude et al., 2013). Pemanasan dengan gelombang mikro dapat mempercepat reaksi transesterifikasi dengan menghasilkan yield FAMEs yang tinggi. Proses separasi produk juga menjadi lebih cepat dan mudah (Shakinaz, et al., 2010).

Metode in situ merupakan metode dimana proses ekstraksi minyak dan reaksi minyak dengan metanol terjadi secara simultan dalam satu proses. Penggunaan metode in situ juga diharapkan dapat menjadikan jalur produksi semakin ekonomis. Hal ini diharapkan metode yang di gunakan dapat menjadi visible untuk dikembangkan dalam skala industri. Pengaruh beberapa variabel operasi dalam proses pembuatan biodiesel berbahan baku dedak padi secara in situ dengan menggunakan microwave dipelajari dalam penelitian ini secara sistematis.

\section{Metode Penelitian}

Dedak padi yang diperoleh dari penggilingan padi di pisahkan terlebih dahulu dari zat pengotor yang terikut di dalamnya dan kemudian di simpan dalam lemari pendingin untuk menjaga kandungan asam lemak bebas tidak meningkat. Sebanyak 4 gram dedak padi dicampur dengan metanol dan dimasukkan ke dalam labu alas datar. $\mathrm{NaOH}$ sebesar 0,6 w\% digunakan sebagai katalis basa dalam penelitian ini. Suhu reaksi yang digunakan adalah $60^{\circ} \mathrm{C}$. Labu alas datar yang dilengkapi dengan kondesor kemudian dimasukkan ke dalam reaktor microwave sesuai waktu reaksi yang telah ditentukan (Asakuma et al., 2011). Hasil reaksi kemudian ditambahkan dengan $n$-heksana untuk mengambil produk yang terbentuk. Proses ini dilakukan sebanyak lima kali. Produk yang bercampur dengan $n$-heksane kemudian didistilasi untuk memisahkan produk dan pelarut $n$-heksana. Produk kemudian dimasukkan ke dalam oven untuk memastikan pelarut tidak ikut dalam produk. Kemudian produk siap untuk dianalisis. 


\section{Analisa FAMEs}

Kandungan FAMEs di setiap produk ditentukan dengan menggunakan analisis GC dengan tipe HP 5890 Series produksi Hewlett-Packard Inc. Sebanyak 0,02 gr sampel produk diencerkan dengan $1 \mathrm{ml}$ heksan selanjutnya diinjeksikan ke dalam GC. Kolom GC yang digunakan adalah kolom Ov-17. Temperatur injektor dan detektor diatur pada $125^{\circ} \mathrm{C}$, meningkat $15^{\circ} \mathrm{C} /$ menit sampai $275^{\circ} \mathrm{C}$ dan dipertahankan pada suhu $275^{\circ} \mathrm{C}$ selama 10 menit. Kecepatan gas pembawa $28 \mathrm{ml} /$ menit pada suhu $200^{\circ} \mathrm{C}$.

$$
\text { FAME yield }(\%)=\frac{\text { Berat Produk }(g) \times \text { Kandungan FAME }(\%)}{\text { Berat Minyak Dedak Padi }(g)} \times 100
$$

\section{Hasil dan Pembahasan}

Fatty acid metil ester (FAMEs) atau lebih dikenal dengan biodiesel merupakan energi terbarukan pengganti solar yang terbuat dari sumber nabati ataupun hewani melalui reaksi transesterifikasi maupun esterifikasi. Pengaruh jumlah metanol dalam proses pembuatan biodiesel dengan menggunakan reaktor microwave dapat dilihat pada Gambar 1 . Dengan menggunakan waktu reaksi 30 menit, kandungan FAMEs di dalam produk meningkat dengan kenaikan jumlah metanol yang digunakan. Pada penggunaan metanol $60 \mathrm{ml}$, kandungan FAMEs dalam produk adalah 2,5477\% dan sedikit meningkat menjadi 3,2431\% saat metanol yang digunakan meningkat menjadi $100 \mathrm{ml}$. Secara stiokiometri, 3 mol metanol dibutuhkan untuk bereaksi dengan 1 mol trigliserida untuk menghasilkan 3 mol FAMEs. Metanol berlebih digunakan dalam reaksi ini dikarenakan selain menjadi reaktan, metanol juga digunakan sebagai pelarut ektraksi minyak dedak padi. Kelarutan reaktan meningkat dengan semakin banyaknya metanol yang digunakan (Musa, 2016). Selain itu penggunaan metanol berlebih juga bertujuan untuk menggeser kesetimbangan reaksi ke arah pembentukan produk yaitu FAMEs dan gliserol (Sharma et al., 2018).

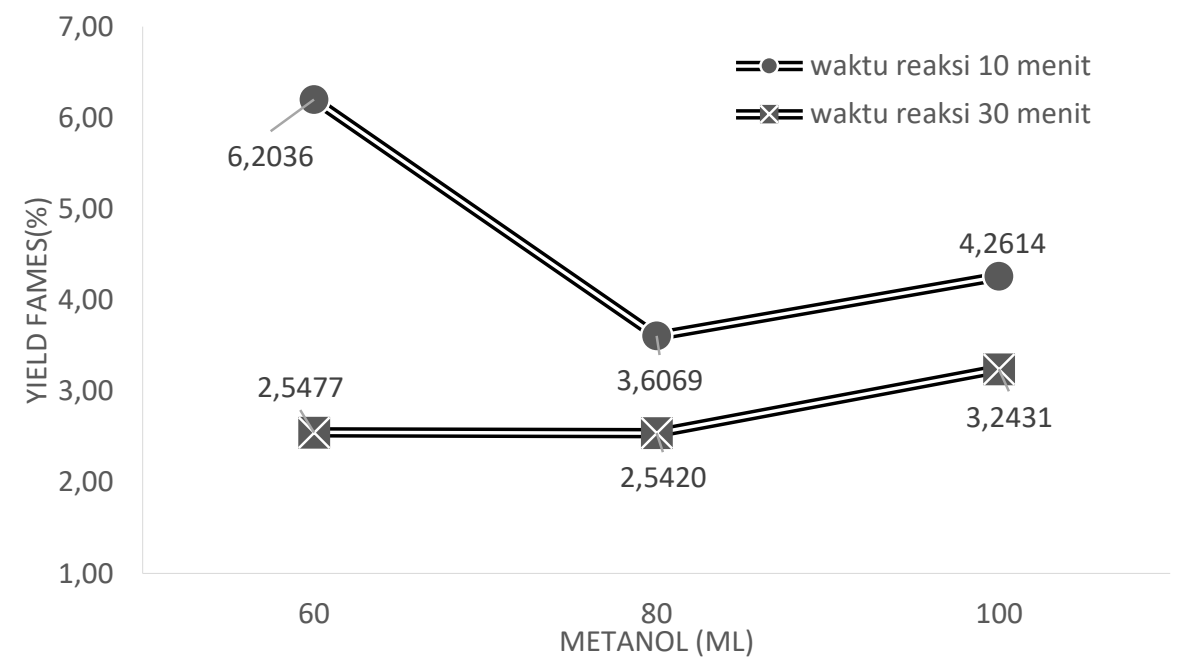

Gambar 1. Pengaruh jumlah metanol terhadap $\%$ yield FAMEs yang diperoleh pada waktu reaksi 10 dan 30 menit

Kecenderungan berbeda diperoleh saat reaksi berlangsung pada waktu yang lebih singkat yaitu 10 menit. Kandungan
FAMEs dalam produk adalah 6,2036\% diperoleh saat metanol $60 \mathrm{ml}$ digunakan dalam reaksi dan menurun secara 
signifikan menjadi 3,6069\% saat metanol yang digunakan meningkat menjadi 80 $\mathrm{ml}$. Saat metanol terus dinaikan menjadi $100 \mathrm{ml}$, kandungan FAMEs mengalami sedikit kenaikan menjadi 4,2614\%. Hal ini mungkin disebabkan dengan kenaikan jumlah metanol, maka komponen yang lebih polar daripada minyak dedak padi seperti komponen protein, dan kardohidrat lebih cenderung diektraksi oleh metanol dibandingkan minyak dedak padi (Shiu et al., 2010). Hal ini yang menyebabkan kandungan FAMEs mengalami penurunan dengan kenaikan jumlah metanol.

Waktu reaksi 10 menit secara keseluruhan memberikan kandungan FAMEs yang lebih tinggi jika dibandingkan dengan waktu reaksi 30 menit. Hal ini menunjukan bahwa reaktor microwave dapat mengkonversi minyak dedak padi menjadi FAMEs dengan waktu yang lebih singkat. Kenaikan waktu reaksi menurunkan kandungan FAMEs dalam produk.

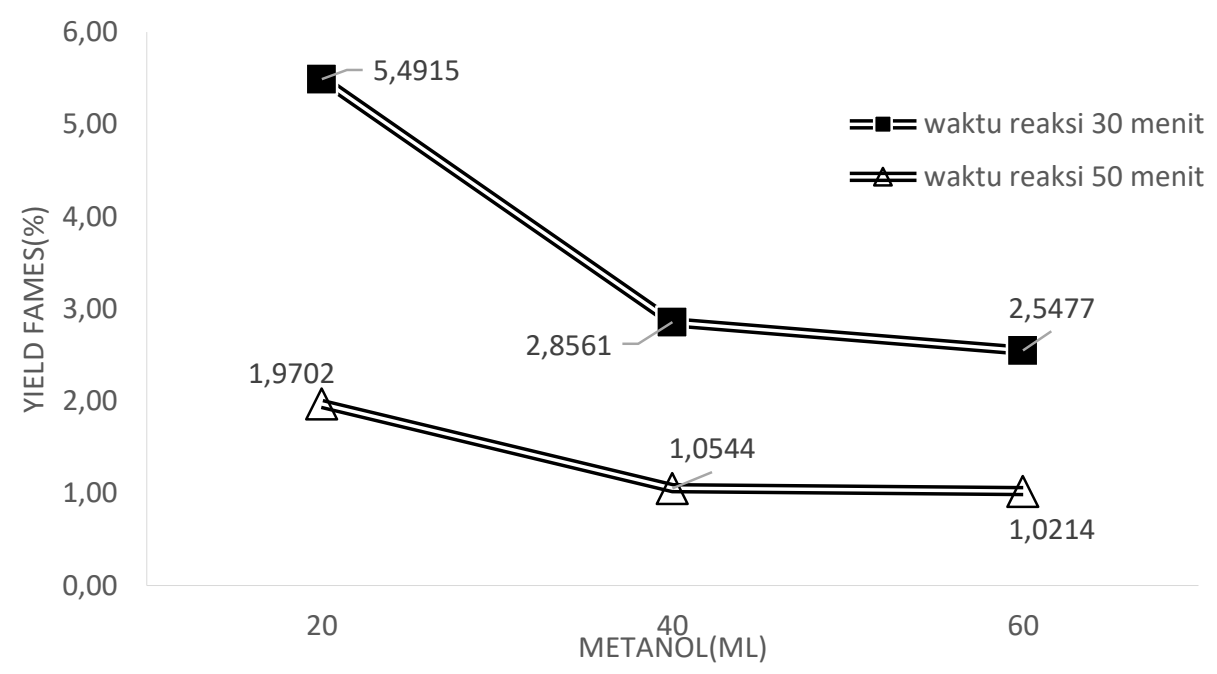

Gambar 2. Pengaruh jumlah metanol terhadap \% yield FAMEs yang diperoleh pada waktu reaksi 30 dan 50 menit

Interaksi microwave dengan komponen reaksi menghasilkan pengurangan energi aktivitas yang besar sebagai akibat peningkatan fenomena polarisasi dipolar (Gude et al., 2013). Dari Gambar 2 dapat dilihat bahwa pada waktu reaksi 30 dan 50 menit dan disertai kenaikan jumlah metanol dari $20 \mathrm{ml}$ ke $60 \mathrm{ml}$ menyebabkan penurunan kandungan FAMEs dalam produk. Penurunan cukup signifikan terjadi pada waktu reaksi 30 menit dimana kandungan FAMEs menurun dari 5,4915 \% menjadi $2,5477 \%$ dengan kenaikan jumlah metanol. Waktu reaksi 30 menit memberikan hasil yang lebih baik jika dibandingkan dengan waktu reaksi 50 menit. Kandungan
FAMEs dalam produk lebih besar diperoleh pada waktu lebih singkat saat menggunakan reaktor microwave. Gelombang mikro sukses mempercepat terjadinya reaksi transesterifikasi antara minyak dedak padi dan metanol dibandingkan dengan metode konventional (Rahkadima dan A'yuni, 2017). Secara umum, peningkatan waktu reaksi dapat meningkatkan konversi reaktan menjadi produk namun dikarenakan reaksi transesterifikasi adalah reaksi bolak balik maka peningkatan waktu reakis melebihi waktu optimum akan menyebabkan reaksi berbalik arah yang menyebabkan produk FAMEs yang terbentuk terurai kembali.

\section{Kesimpulan}


Biodiesel berhasil diproduksi secara in situ menggunakan reaktor microwave yang telah dimodifikasi. Pada penggunaan reaktor microwave, dengan waktu yang lebih singkat kandungan FAMEs dalam produk yang lebih tinggi dapat diperoleh.

\section{Daftar Pustaka}

Asakuma, Y., Ogawa, Y., Maeda, K., Fukui, K., Kuramochi, H., 2011, Effects of microwave irradiation on triglyceride transesterification: Experimental and theoretical studies, Biochemical Engineering Journal, 58-59, 20-24.

Astawan, M. dan Febrinda, A.E., 2010, Potensi dedak dan bekatul beras sebagai ingredient pangan dan produk pangan fungsional, Jurnal Pangan, 19(1), 14-21.

Gude, V.G., Patil, P, Martinez-Guerra, E, Deng, S., Nirmalakhandan, N., 2013, Review Microwave energy potential for biodiesel production. Sustainable Chemical Processes, $1,5$.

Lin Lin, Dong Ying, Sumpun Chaitep, Saritporn Vittayapadung, 2009, Biodiesel production from crude rice bran oil and properties as fuel, Applied Energy, 86, 681-688.

Musa, I.A., 2016, The effects of alcohol to oil molar ratios and the type of alcohol on biodiesel production using transesterification process, Egyptian Journal of Petroleum, 25, 21-31.
Kandungan FAMEs tertinggi yaitu $6,2036 \%$ yang diperoleh pada waktu reaksi tersingkat yaitu 10 menit, volume metanol $60 \mathrm{ml}$ dan suhu reaksi $60^{\circ} \mathrm{C}$.

Rahkadima, Y. dan A'yuni, Q., 2017, Transesterifikasi Minyak Dedak Padi Secara In-Situ Dengan Bantuan Gelombang Mikro, Journal of Research and Technology, 3(2), 54-62.

Rahkadima, Y. dan A'yuni, Q., 2017, Produksi Biodiesel Dari Dedak Padi Menggunakan Metode In Situ Dengan Bantuan Microwave, Seminar Nasional Sains \& Teknologi II, Malang: Universitas Brawijaya.

Shakinaz, E., Sherbiny, A.A., Refaat, T., Shakinaz, E., Sheltaway, Production of biodiesel using the microwave technique, J Adv. Res., 1(4), 309314.

Shiu, P., Setiyo Gunawan, Wen-Hao Hsieh, Novy S. Kasim, Yi-Hsu Ju, 2010, Biodiesel production from rice bran by a two-step in-situ process, Bioresource Technology, 101, 984-989. 